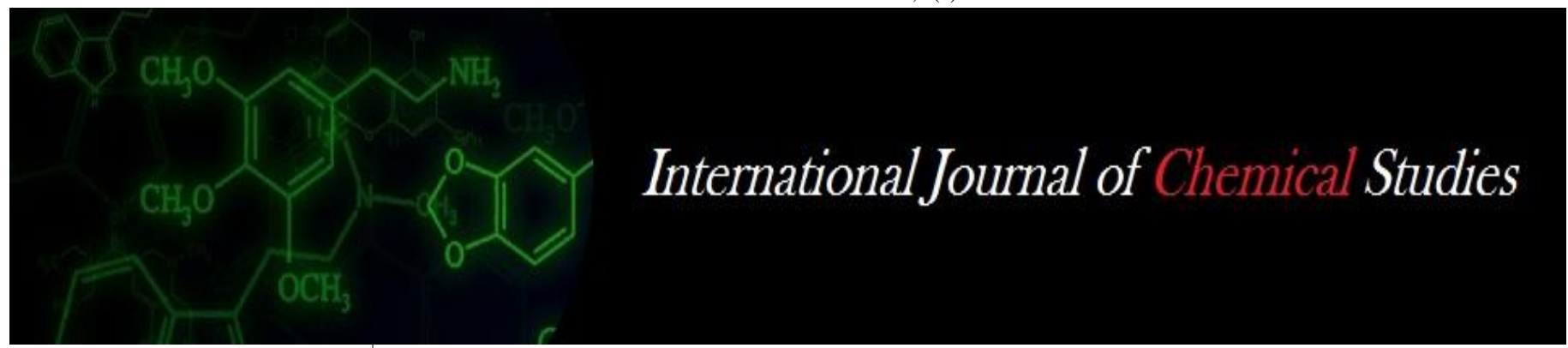

P-ISSN: 2349-8528

E-ISSN: 2321-4902

IJCS 2020; 8(1): 2102-2105

(C) 2020 IJCS

Received: 18-11-2019

Accepted: 22-12-2019

\section{Amandeep Singh}

Department of Crop

Improvement, CSK HPKV,

Palampur, Himachal Pradesh,

India

\section{RK Mittal}

Department of Crop

Improvement, CSK HPKV,

Palampur, Himachal Pradesh,

India

\section{VK Sood}

Department of Crop

Improvement, CSK HPKV,

Palampur, Himachal Pradesh,

India

Kulveer Singh Dhillon

Department of Crop

Improvement, CSK HPKV,

Palampur, Himachal Pradesh,

India

\section{Sawan Kumar}

Department of Crop

Improvement, CSK HPKV,

Palampur, Himachal Pradesh, India
Corresponding Author:

Amandeep Singh

Department of Crop

Improvement, CSK HPKV,

Palampur, Himachal Pradesh,

India

\section{Studies on heterosis and per se performance in early Segregant population of Urdbean (Vigna mungo L. Hepper)}

\author{
Amandeep Singh, RK Mittal, VK Sood, Kulveer Singh Dhillon and \\ Sawan Kumar
}

DOI: https://doi.org/10.22271/chemi.2020.v8.i1ae.8577

\begin{abstract}
The present investigation consisted of six Urdbean cultivars and fifteen crosses developed using half diallel mating design to study the mean performance of genotypes and heterosis among the crosses. The crosses $\left(\mathrm{F}_{2}\right.$ 's) along with the parental genotypes were grown in a randomized block design with three replications at Experimental Farm of the Department of Crop Improvement, CSK HPKV Palampur (H.P.) during Kharif, 2018. The data were recorded for yield and yield contributing traits. Mean performance and standard heterosis is studied over the check variety i.e. Palampur-93. Analysis of variance revealed that there was sufficient variability among the parental lines and cross combinations. Standard heterosis for seed yield per plant ranged from -36.25 per cent (IC-281994 X DU-1) to 34.55 per cent (HPBU-111× KU-553). Significant positive heterosis for seed yield was observed in only one cross HPBU-111× KU$553(34.55 \%)$, whereas seven crosses were statistically at par with the check. Thirteen genotypes were recorded significantly superior to the check for mean value of seed yield per plant. Mean value for this trait ranged from $2.29 \mathrm{~g}$ to $3.45 \mathrm{~g}$. On the basis of per se performance for physiological and yield related traits, three crosses viz., HPBU-111 × KU-553, Palampur-93 $\times$ IC-281994 and Him Mash $\times$ KU-553 were identified as best cross combinations. These crosses can be further evaluated at Multilocations for commercial exploitation.
\end{abstract}

Keywords: Blackgram, heterosis, Urdbean, Vigna mungo L.

\section{Introduction}

Urdbean [Vigna mungo (L). Hepper] popularly known as blackgram or mash, is a self pollinated diploid grain legume $(2 \mathrm{n}=2 \mathrm{x}=22)$, belongs to the Leguminaceae family and Papilionaceae, subfamily, with genome size of $560 \mathrm{mb}$ (Arumuganath and Earle, 1991). Vigna mungo var. silvestris, grows wild in India and believed to be progenitor of blackgram (Lukoki et al., 1980) ${ }^{[7]}$. It is an economically important grain legume crop in Asia, widely cultivated on marginal lands with low inputs during Kharif, Rabi and summer seasons. It has been reported to be originated in India with a secondary centre of origin in central Asia (Pratap and Kumar 2011) ${ }^{[10]}$. The area of traditional cultivation of Urdbean is confined to the South Asia and adjacent areas including India, Pakistan, Afghanistan, Bangladesh and Myanmar. India is the largest producer as well as consumer of Urdbean, contributing nearly 70 per cent of World's production, followed by Myanmar and Thailand (Anonymous 2018a) ${ }^{[1]}$. It accounts for about 15 per cent of India's total pulse production, cultivated in 4.49 million hectares area and producing 2.93 million tonnes with an average productivity of $500 \mathrm{~kg}$ per ha (Anonymous 2017) ${ }^{[2]}$. The discovery of hybrid vigour by Shull (1908) ${ }^{[13]}$ opened a new era of "Heterosis Breeding" for crop improvement. Heterosis is expressed in three ways, depending on the criteria used to compare the performance of a hybrid. The three ways are: mid-parent, standard variety and better parent heterosis. However, from the plant breeders ${ }^{\text {ee }}$ viewpoint, better parent (heterobeltiosis) and or standard variety (standard heterosis) are more effective.

In Urdbean, exploiting hybrid vigour through hybrids is a difficult task thus, only alternative appears to exploit inbred vigour. Therefore, the genetic improvement in self pollinated crops, like Urdbean would mainly depend upon how much this vigour is heritable. Therefore, the best approach to exploit the outstanding crosses obtained through the present study is to defer selection in the later generation by advancing segregating material though bulk or single seed decent (SSD) method. During the process, non-additive gene action may constantly be 
converted into additive gene action due to frequent opportunity for recombination and selection will guide evolution by promoting additive gene action towards the breeder's demand. So, the present investigation is carried out with the objective to evaluate the Urdbean cultivars and crosses for heterosis and mean performance.

\section{Material and Methods}

The experimental material consisted of the six parents viz., Palampur-93, HPBU-111, DU-1, KU-553, Him Mash-1 and IC-281994, and $15 \mathrm{~F}_{2}$ 's among these cultivars of Urdbean. The $F_{2}$ segregants along with the parental genotypes were grown in a randomized block design (RBD) with three replications at Experimental Farm of the Department of Crop Improvement, CSK HPKV Palampur (H.P.) during Kharif, 2018. Each replication comprised two rows of $1.5 \mathrm{~m}$ length with spacing of $30 \times 10 \mathrm{~cm}$. The data were recorded on twenty randomly taken plants from each cross across replications for all the traits studied except days to 50 per cent flowering and days to 75 per cent maturity which were recorded on plot basis. The statistical analysis of variance for randomized block design was carried out by standard procedure given by Panse and Sukhatme (1984) ${ }^{[8]}$. The estimates of standard heterosis were calculated as the deviation of F2 mean from the standard check. The ' $t$ ' calculated values for heterosis over standard check was compared with ' $t$ ' tabulated value at error degree of freedom and $\mathrm{P}=0.05$. The ' $\mathrm{t}$ ' calculated value $\geq$ ' $\mathrm{t}$ ' tabulated values were marked significant and an asterisk $(*)$ was put on per cent values only.

\section{Results and Discussion}

Mean performance of parents and crosses

Analysis of variance revealed that there was sufficient variability among the genotypes for all the characters studied except harvest index (Table 1).

Mean performance of parents and crosses were studied for all the characters is given in Table 2. For days to 50 percent flowering, nine genotypes were significantly superior than the check i.e. Palampur-93. Mean value for this trait ranged from 42.33 to 58.00 days. Fourteen genotypes were significantly superior to the check for days to 75 percent maturity. Mean value for days to 75 percent maturity ranged from 74.67 to 81.67 days. Among 21 black gram genotypes, only three genotypes i.e. HPBU-111, Him Mash-1 $\times$ HPBU-111 and Him Mash-1 $\times$ KU-553 were found to be superior as compare to the check for plant height. Mean value for plant height ranged from $12.60 \mathrm{~cm}$ to $18.43 \mathrm{~cm}$. Only two genotypes were significantly superior for branches per plant over the check variety. Mean value for this character ranged from 1.53 to 2.78. None of the entry was significantly superior for pods per plant over check. Mean value for pods per plant ranged from 6.53 to 11.07. For pod length, only two genotypes were superior than the check and mean value ranged from $3.80 \mathrm{~cm}$ to $4.58 \mathrm{~cm}$. Mean value for seeds per pod ranged from 4.10 to 5.19 and eight genotypes were recorded significantly superior than the check variety. For 100 seed weight, all 21 genotypes were significantly superior over the check Palampur 93, except four genotypes. Mean value for this character ranged from $3.38 \mathrm{~g}$ to $5.47 \mathrm{~g}$. For seed yield per plant, thirteen genotypes were recorded significantly superior than the check i.e. Palampur-93. Mean value ranged from $2.29 \mathrm{~g}$ to $3.45 \mathrm{~g}$ for seed yield per plant. Sixteen genotypes were significantly superior to the check for biological yield per plant. Mean value for biological yield per plant ranged from $7.78 \mathrm{~g}$ to 14.33 g. For harvest index, only three were found significantly superior than the check. Mean value ranged from 19.61 to 34.39 .

Table 1: Analysis of variance of RBD with respect to different traits studied

\begin{tabular}{|c|c|c|c|c|}
\hline \multirow{3}{*}{ S. No. } & \multirow{2}{*}{ Traits } & \multicolumn{3}{|c|}{ Mean sum of squares } \\
\hline & & Replication & Genotypes & Error \\
\hline & Degree of Freedom & 2 & 20 & 40 \\
\hline 1 & Day to 50 per cent flowering & 6.11 & $31.154 * *$ & 2.035 \\
\hline 2 & Days to 75 per cent maturity & 1.76 & $9.533 * *$ & 1.145 \\
\hline 3 & Plant height $(\mathrm{cm})$ & 16.31 & $21.85 * *$ & 5.595 \\
\hline 4 & Branches per plant & 0.018 & $0.323 * *$ & 0.128 \\
\hline 5 & Pods per plant & 6.24 & $4.071^{*}$ & 2.079 \\
\hline 6 & Pod length $(\mathrm{cm})$ & 0.038 & $0.139 * *$ & 0.022 \\
\hline 7 & Seeds per pod & 0.007 & $0.237 * *$ & 0.059 \\
\hline 8 & 100-seed weight $(\mathrm{g})$ & 0.0715 & $0.944 * *$ & 0.128 \\
\hline 9 & Seed yield per plant $(\mathrm{g})$ & 0.589 & $10.77 * *$ & 0.72 \\
\hline 10 & Biological yield per plant $(\mathrm{g})$ & 2.78 & $10.717 *$ & 5.766 \\
\hline 11 & Harvest Index (\%) & 18.49 & 42.257 & 25.737 \\
\hline
\end{tabular}

* Significant at 5 per cent level of significance

** Significant at 1 per cent level of significance

Table 2: Mean values of parents and crosses for different traits

\begin{tabular}{|c|c|c|c|c|c|c|c|c|c|c|c|c|}
\hline Sr. no. & Traits & DF & DM & PH & $\mathbf{B P}$ & PP & PL & SP & BY & SY & HI & SW \\
\hline 1 & Him Mash-1 & 48.67 & 77.67 & 14.13 & 2.10 & 8.37 & 4.40 & 5.18 & 8.40 & 2.88 & 34.39 & 4.56 \\
\hline 2 & PLP93 & 50.33 & 79.00 & 18.10 & 2.47 & 11.07 & 4.50 & 4.93 & 8.80 & 2.76 & 31.89 & 3.90 \\
\hline 3 & HPBU111 & 54.00 & 77.00 & 18.13 & 1.60 & 8.27 & 4.12 & 4.63 & 9.00 & 2.41 & 28.04 & 4.23 \\
\hline 4 & IC281994 & 50.33 & 74.67 & 12.60 & 1.53 & 6.53 & 4.30 & 4.10 & 8.00 & 2.29 & 32.40 & 4.26 \\
\hline 5 & DU-1 & 48.00 & 77.00 & 14.53 & 2.13 & 9.87 & 4.43 & 5.00 & 10.13 & 2.47 & 31.11 & 3.63 \\
\hline 6 & KU553 & 50.00 & 80.00 & 13.37 & 1.98 & 9.68 & 4.44 & 4.83 & 14.33 & 2.82 & 19.61 & 3.73 \\
\hline 7 & Him Mash-1 $\times$ Palampur-93 & 50.00 & 77.33 & 16.29 & 1.72 & 7.70 & 4.40 & 4.98 & 8.52 & 2.76 & 32.96 & 4.69 \\
\hline 8 & Him Mash-1 × HPBU-111 & 48.67 & 77.33 & 18.43 & 2.45 & 9.40 & 4.11 & 4.89 & 12.17 & 3.09 & 25.38 & 4.87 \\
\hline 9 & Him Mash-1 × IC-281994 & 54.00 & 77.00 & 14.68 & 2.09 & 8.55 & 4.04 & 4.83 & 10.03 & 2.80 & 28.47 & 4.11 \\
\hline 10 & Him Mash-1 × DU-1 & 58.00 & 76.33 & 14.18 & 1.84 & 8.50 & 4.28 & 4.76 & 11.63 & 2.64 & 26.20 & 4.95 \\
\hline 11 & Him Mash-1 × KU-553 & 51.00 & 75.33 & 18.26 & 2.46 & 10.65 & 3.93 & 5.16 & 11.21 & 3.25 & 29.07 & 4.52 \\
\hline
\end{tabular}




\begin{tabular}{|c|c|c|c|c|c|c|c|c|c|c|c|c|}
\hline 12 & Palampur-93 $\times$ HPBU-111 & 51.67 & 79.00 & 13.35 & 2.10 & 8.28 & 4.66 & 5.02 & 9.58 & 2.85 & 30.47 & 5.05 \\
\hline 13 & Palampur-93 × IC-281994 & 48.33 & 78.33 & 16.16 & 2.49 & 9.55 & 4.27 & 4.65 & 11.90 & 3.31 & 28.08 & 5.47 \\
\hline 14 & Palampur-93 × DU-1 & 45.33 & 76.00 & 16.54 & 2.33 & 9.09 & 4.30 & 4.90 & 10.27 & 3.03 & 29.42 & 4.25 \\
\hline 15 & Palampur-93 × KU-553 & 48.00 & 78.00 & 15.61 & 2.31 & 9.58 & 4.55 & 5.12 & 10.88 & 3.15 & 28.77 & 5.19 \\
\hline 16 & HPBU-111 × IC-281994 & 52.67 & 80.67 & 13.87 & 2.21 & 8.82 & 4.58 & 4.85 & 11.63 & 2.76 & 23.68 & 4.76 \\
\hline 17 & HPBU-111×DU-1 & 48.33 & 81.67 & 15.07 & 2.15 & 8.69 & 4.21 & 5.19 & 10.25 & 2.99 & 30.25 & 5.06 \\
\hline 18 & HPBU-111× KU-553 & 51.67 & 79.33 & 15.85 & 2.78 & 10.91 & 4.25 & 4.90 & 14.00 & 3.45 & 24.47 & 5.12 \\
\hline 19 & IC-281994 × DU-1 & 42.33 & 77.33 & 14.94 & 1.59 & 6.94 & 3.80 & 4.21 & 7.78 & 2.37 & 30.30 & 3.38 \\
\hline 20 & IC-281994 × KU-553 & 50.33 & 76.00 & 14.43 & 2.22 & 8.30 & 4.44 & 4.90 & 12.08 & 2.98 & 24.91 & 4.20 \\
\hline \multirow[t]{3}{*}{21} & DU-1 $\times$ KU-553 & 49.67 & 76.00 & 15.57 & 2.07 & 8.89 & 4.35 & 5.04 & 12.95 & 2.92 & 22.41 & 4.33 \\
\hline & $\mathrm{CD}$ at $5 \%$ & 2.36 & 1.77 & 3.49 & 0.59 & 2.38 & 0.25 & 0.40 & 3.47 & 0.82 & 8.18 & 0.59 \\
\hline & $\mathrm{CV}$ & 2.84 & 1.37 & 13.65 & 16.82 & 16.13 & 3.44 & 5.01 & 16.04 & 17.47 & 17.98 & 7.96 \\
\hline
\end{tabular}

Note: SY, Seed yield; SW, 100 seed weight; SP, Seeds per pod; PL, Pod length; BY, biological yield; HI, harvest index; DF, days to 50\% Flowering; DM, days to 75\% maturity; PH, plant height; PP, Pods per plant; BP, Branches per plant

\section{Heterosis for all the characters over the standard check}

The value of standard heterosis is given in Table 3. For physiological traits like days to 50 per cent flowering and days to 75 per cent maturity, negative estimates of the heterotic values are desirable to the plant breeder mainly to infuse earliness in the genotype. Hence more attention was given towards the negative value of these traits. The range for standard heterosis for days to 50 per cent flowering was 15.89 per cent $($ IC-281994 $\times$ DU-1) to 15.23 per cent $(\mathrm{Him}$ Mash-1 $\times$ DU-1). Significant negative heterosis was observed in only one cross IC-281994 × DU-1 (-15.89) and seven crosses were at par to the standard check. For days to 75 per, nine cross-combinations showed significant negative values for standard heterosis, ranged from -4.64 per cent (Him Mash$1 \times \mathrm{KU}-553)$ to 0.42 per cent (HPBU-111× KU-553). The best three crosses were Him Mash-1 $\times$ KU-553 (-4.64), Palampur-93 × DU-1 (-3.80), DU-1 × KU-553 (-3.80) and two crosses were at par for this trait. The standard heterosis for plant height ranged from -26.22 per cent (Palampur-93 x HPBU-111) to 1.80 per cent (Him Mash-1 × HPBU-111). None of the crosses had significant positive standard heterosis for the trait and two crosses Him Mash-1 $\times$ HPBU-111 and Him Mash-1 $\times$ KU-553 are at par to the standard check. For branches per plant, none of the crosses had significant positive heterosis. However, two crosses Palampur-93 $\times$ IC281994 and HPBU-111× KU-553 were at par to the standard check. The range of standard heterosis was -35.41 per cent $(\mathrm{IC}-281994 \times$ DU-1) to 12.57 per cent (HPBU-111× KU553). The range of heterosis for pods per plant was recorded 33.27 per cent $(\mathrm{IC}-281994 \times \mathrm{DU}-1)$ to 4.90 per cent $(\mathrm{HPBU}-$ $111 \times$ KU-553). None of the crosses had significant positive heterosis for this character. However, three crosses Him Mash-1 × KU-553, Palampur-93 × IC-281994 and HPBU$111 \times \mathrm{KU}-553$ were recorded statistically at par with the check. The range of heterosis for pod length was recorded from -15.56 per cent $(\mathrm{IC}-281994 \times$ DU-1) to 3.48 per cent
(Palampur-93 $\times$ HPBU-111). None of the crosses had significant positive heterosis for the trait and three crosses Palampur-93 × HPBU-111, Palampur-93 × KU-553 and HPBU-111 $\times$ IC-281994 were at par for this trait. The range of standard heterosis recorded for this trait was -11.63 per cent (IC-281994 $\times$ DU-1) to 59.09 per cent (HPBU-111× KU553). Six crosses showed significant positive heterosis out of which the maximum magnitude was observed in HPBU-111x KU-553 (59.09\%) followed by DU-1 × KU-553 (47.16\%) and Him Mash-1 $\times$ HPBU-111 (38.30\%) and 7 crosses were at par with the standard check. None of the crosses had significant positive heterosis for the trait. However, six crosses viz., Him Mash-1 × Palampur-93, Him Mash-1 × KU-553, Palampur-93 $\times$ HPBU-111, Palampur-93 × KU-553, HPBU-111× DU-1 and DU- $1 \times$ KU-553 were at par with the check. The heterosis ranged from -14.59 per cent (IC-281994 $\times$ DU-1) to 5.20 per cent (HPBU-111× DU-1) for seeds per pod. Standard heterosis ranged from -36.25 per cent (IC-281994 $\times$ DU-1) to 34.55 per cent (HPBU-111× KU-553) for seed yield per plant. Significant positive heterosis for seed yield was observed in only one cross HPBU-111× KU-553 (34.55\%), whereas seven crosses were statistically at par. No cross combination exhibited significantly positive heterosis over the standard check for harvest index. Heterosis ranged from -33.65 per cent (DU-1 $\times$ KU-553) to -1.14 per cent (Palampur-93 $\times$ KU553) for this character. Among 15 crosses, seven crosses had significant positive heterosis for the trait out of which Palampur-93 × KU-553 (33.16\%), HPBU-111× KU-553 $(31.17 \%)$ and Him Mash-1 $\times$ DU-1 (26.92\%) had the maximum magnitude. The range of heterosis was recorded 13.25 per cent (IC-281994 $\times$ DU-1) to 33.16 per cent (Palampur-93 $\times$ KU-553). Seven crosses were found at par with the standard check for this trait. These results were also in the favour of findings of Ramakant and Srivastava et al. (2012), Karande et al. (2013) ${ }^{[11,5]}$ in Urdbean.

Table 3: Estimates of standard heterosis (\%) over standard check for different traits

\begin{tabular}{|c|c|c|c|c|c|c|c|c|c|c|c|c|}
\hline Sr. no. & Traits & DF & DM & PH & BP & $\mathbf{P P}$ & PL & SP & BY & SY & HI & SW \\
\hline & Crosses & & & & & & & & & & & \\
\hline 1 & Him Mash-1 × Palampur & .66 & $.11 *$ & -10.00 & $-30.14 *$ & $-25.93 *$ & -2.30 & 95 & -3.22 & -5.80 & -2.40 & $0.17 *$ \\
\hline 2 & Him Mash-1 × HPBU-111 & -3.31 & $-2.11^{*}$ & 1.80 & -0.68 & -6.44 & $-8.67 *$ & -0.88 & $38.30^{*}$ & 22.27 & -12.61 & $24.87 *$ \\
\hline 3 & Him Mash-1 × IC-281994 & $7.28 *$ & $-2.53 *$ & -18.90 & -15.27 & -17.82 & $-10.22 *$ & -2.09 & 13.98 & -4.43 & -15.70 & 5.30 \\
\hline 4 & Him Mash-1 × DU-1 & $15.23 *$ & $-3.38 *$ & $-21.68 *$ & $-25.54 *$ & -18.30 & -4.81 & -3.51 & 13.22 & -9.89 & -17.32 & $26.92 *$ \\
\hline 5 & & 1.32 & $-4.64 *$ & 0.90 & -0. & 8.8 & $-12.74 *$ & 4.59 & 27.42 & 10.91 & -13.91 & 15.98 \\
\hline 6 & $3 \times$ & 2.65 & 0.00 & $-26.22 *$ & -14.86 & $-20.42 *$ & 3.48 & 1.76 & 8.83 & -2.84 & -9.78 & 29.57 \\
\hline 7 & ampur-93 × IC-281994 & -3.97 & -0.84 & -10.70 & 0.81 & 1.70 & -5.19 & -5.74 & $35.27 *$ & 12.95 & -16.86 & 40.26 \\
\hline 8 & Palampur-93 × DU-1 & -9.93 & $-3.80 *$ & -8.60 & -5.68 & -12.60 & -4.37 & -0.68 & 16.74 & 3.41 & -12.89 & 8.89 \\
\hline 9 & npur-93 × KU-553 & -4.64 & -1.27 & -13.74 & -6.49 & -7.88 & 1.19 & 3.78 & 23.67 & 24.32 & -1.14 & $33.16^{*}$ \\
\hline 10 & $111 \times I$ & 4.64 & $2.11 *$ & $-23.39 *$ & -10.54 & -15.16 & 1.78 & -1.69 & $32.12 *$ & -5.80 & $-29.88^{*}$ & 21.97* \\
\hline 11 & HPBU-111× DU-1 & -3.97 & $3.38 *$ & -16.76 & -12.84 & -16.44 & $-6.52 *$ & 5.20 & 16.48 & 2.05 & -10.42 & $29.83^{*}$ \\
\hline
\end{tabular}




\begin{tabular}{|c|c|c|c|c|c|c|c|c|c|c|c|c|}
\hline 12 & HPBU-111× KU-553 & 2.65 & 0.42 & -12.41 & 12.57 & 4.90 & -5.48 & -0.68 & $59.09 *$ & $34.55^{*}$ & -17.17 & $31.37 *$ \\
\hline 13 & IC-281994 × DU-1 & $-15.89 *$ & $-2.11 *$ & -17.46 & $-35.41 *$ & $-33.27 *$ & $-15.56^{*}$ & $-14.59 *$ & -11.63 & $-36.25^{*}$ & $-29.47 *$ & -13.25 \\
\hline 14 & IC-281994 × KU-553 & 0.00 & $-3.80^{*}$ & $-20.26 *$ & -10.00 & -20.16 & -1.33 & -0.68 & $37.31 *$ & 1.70 & $-26.31^{*}$ & 7.69 \\
\hline 15 & DU-1 $\times$ KU-553 & -1.32 & $-3.80^{*}$ & -14.00 & -15.95 & -14.52 & -3.26 & 2.23 & $47.16^{*}$ & -0.34 & $-33.65^{*}$ & 11.03 \\
\hline
\end{tabular}

*Significant at 5 per cent level of significance

Note: SY, Seed yield; SW, 100 seed weight; SP, Seeds per pod; PL, Pod length; BY, biological yield; HI, harvest index; DF, days to 50\% Flowering; DM, days to 75\% maturity; PH, plant height; PP, Pods per plant; BP, Branches per plant

\section{Conclusion}

In the present investigation, there was sufficient variability was recorded among the genotypes for most of the traits studied. Good amount of heterosis in $\mathrm{F}_{2}$ generation for a number of crosses with respect to seed yield and its contributing traits was observed. Various workers also reported similar type of findings Elangaimannam et al. (2006), Parveen et al. (2012) and Kumar et al. (2012) ${ }^{[9,6]}$, in Urdbean and Sharma et al. (2019) ${ }^{[12]}$ in Urdbean. On the basis of per se performance for physiological and yield related traits, three lines viz., Him Mash-1, KU-553 and DU-1 were selected as promising genotypes. Whereas, three cross combinations viz., HPBU-111 × KU-553, Palampur-93 × IC281994 and Him Mash $\times$ KU-553 were identified as best cross combinations. These selected lines could be involved into further breeding programmes. The selected crosses can be further evaluated at Multilocation for commercial exploitation.

\section{References}

1. Anonymous. Blackgram or Urdbean. https://kvk.icar.go v.in/API/Content/PPupload/k0222_4.pdf, 2018a.

2. Anonymous. Data on pulses IIPR Kanpur. http://iipr.res.i n/e-pulse-databook.html, 2017.

3. Arumuganathan K, Earle ED. Nuclear DNA Content of Some Important Plant Species. Plant Molecular Biology Reporter. 1991; 9:208-218

4. Elangaimannan R, Anbuselvam Y, Venkatesan M, Karthikeyan P. Heterosis and inbreeding depression for yield and yield attributes in Urdbean. Madras Agriculture Journal. 2006; 95:453-457

5. Karande SP, Rewale AP, Nilakh SB. Combining ability analysis in black gram. (Vigna mungo (L.) Hepper). Bioinfolet. 2013; 10:685-688

6. Kumar GV, Vanaja M, Reddy PRR, Salini K, Abraham B, Lakshmi NJ. Studies on Combining ability and genetic advance in blackgram (Vigna mungo L. Hepper) under rainfed condition. Journal of Agriculture and Allied Sciences. 2012; 3:14-24

7. Lukoki L, Marechal R, Otoul E. Les ancetres sauvages des haricots cultives: Vigna radiata (L.) Wilczek et $V$. mungo (L.) Hepper. Bulletin du Jardin Botanique National de Belgique. 1980; 50:385-391

8. Panse VG, Sukhatme PV. Statistical Methods for Agricultural Workers. Indian Council of Agricultural Research, New Delhi, 1984, 381.

9. Parveen IS, Redi SM, Reddy DM, Suhakar P. Heterosis and combining ability for yield and yield components in Urdbean [Vigna mungo (L.) Hepper]. Journal of Agriculture and Allied Sciences. 2012; 3:14-44.

10. Pratap A, Kumar J. History, origin and evolution. In: Pratap A, Kumar J (eds.) Biology and Breeding of food legumes, CAB International., Oxfordshire, United Kingdom, 2011, 7p.

11. Ramakant, Srivastava RK. Inheritance of some quantitative characters in Urdbean (Vigna mungo (L.) Hepper). Journal of Food Legumes. 2012; 25:1-8
12. Sharma N, Mittal RK, Sood VK, Sharma S. Heterosis for Earliness, Yield and Quality Traits in Urdbean (Vigna mungo (L.) Hepper), Int. J Pure App. Bio sci. 2019; 7(2):190-197

13. Shull GH. Principles of Plant Breeding. New York, London, John Wiley \& Sons, 1908, 226. 